\title{
Involvement of companions in patient safety in pediatric and neonatal units: scope review
}

Envolvimento dos acompanhantes na segurança do paciente em unidades pediátricas e neonatais: revisão de escopo Implicación de los acompañantes en la seguridad del paciente de unidades pediátricas y neonatales: revisión de alcance

\begin{tabular}{r}
\hline Thayane Gusmão Pires de Oliveira' \\
ORCID: 0000-0003-2904-4296 \\
Catharine Galvão Diniz' \\
ORCID: 0000-0002-0620-6435 \\
Marina Peluci Malta Carvalho' \\
ORCID: 0000-0001-5567-8853 \\
Allana dos Reis Corrêa' \\
ORCID: 0000-0003-2208-958X \\
Patrícia Kuerten Rocha" \\
ORCID: 0000-0002-8347-1363 \\
Bruna Figueiredo Manzo' \\
ORCID: 0000-0003-0064-9961
\end{tabular}

'Universidade Federal de Minas Gerais. Belo Horizonte, Minas Gerais, Brazil. "Universidade Federal de Santa Catarina. Florianópolis, Santa Catarina, Brazil.

How to cite this article: Oliveira TGP, Diniz CG, Carvalho MPM, Corrêa AR, Rocha PK, Manzo BF. Involvement of companions in patient safety in pediatric and neonatal units: scope review.

Rev Bras Enferm. 2022;75(3):e20210504. https://doi.org/10.1590/0034-7167-2021-0504

\section{Corresponding author:}

Bruna Figueiredo Manzo

E-mail: brunaamancio@yahoo.com.br

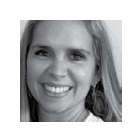

EDITOR IN CHIEF: Antonio José de Almeida Filho ASSOCIATE EDITOR: Hugo Fernandes

Submission: 07-07-2021

Approval: 09-30-2021

\begin{abstract}
Objectives: to describe scientific evidence on the involvement of companions in patient safety, from their own perspective and health professionals' perspective in neonatal and pediatric units. Methods: scoping review carried out according to The Joanna Briggs Institute's recommendations, in eight databases, following the Preferred Reporting Items checklist for Systematic Reviews and Meta-Analyses extension for Scoping Reviews checklist, between 2011 and 2021. Results: the 13 studies included highlighted the importance of companions' involvement in patient safety and the prevention of adverse events. However, they pointed out failures in communication and weakness in the training of professionals, which were obstacles to their involvement. The strengthening of health education, multidisciplinary rounds and educational technologies were highlighted as strategies to expand the involvement of companions. Final Considerations: this study directs elements for health professionals and managers to rethink the companions' role in patient safety and development of collective strategies.

Descriptors: Patient Participation; Family; Patient Safety; Pediatrics; Neonatology.
\end{abstract}

\section{RESUMO}

Objetivos: descrever evidências científicas sobre o envolvimento dos acompanhantes na segurança do paciente, na perspectiva desses e dos profissionais de saúde em unidades neonatais e pediátricas. Métodos: revisão de escopo realizada segundo recomendações do The Joanna Briggs Institute, em oito bases de dados, seguindo o checklist Preferred Reporting Items for Systematic Reviews and Meta-Analyses extension for Scoping Reviews, entre 2011 e 2021. Resultados: os 13 estudos incluídos evidenciaram a importância do envolvimento do acompanhante na segurança do paciente e na prevenção de eventos adversos. Entretanto, apontaram falhas na comunicação e fragilidade na formação dos profissionais, sendo esses dificultadores para o envolvimento. O fortalecimento da educação em saúde, rounds multidisciplinares e tecnologias educativas foram destacadas como estratégias para ampliar o envolvimento dos acompanhantes. Considerações Finais: esse estudo direciona elementos para que profissionais de saúde e gestores repensem a atuação do acompanhante na segurança do paciente e desenvolvam estratégias coletivas.

Descritores: Participação do Paciente; Família; Segurança do Paciente; Pediatria; Neonatologia

\section{RESUMEN}

Objetivos: describir la evidencia científica sobre la implicación de los acompañantes en la seguridad del paciente, desde la perspectiva del susodicho y de los profesionales sanitarios de las unidades neonatales y pediátricas. Métodos: es una revisión de alcance realizada entre 2011 y 2021 en ocho bases de datos, según las recomendaciones del Instituto Joanna Briggs y siguiendo la lista de verificación Preferred Reporting Items for Systematic Reviews and MetaAnalyses extension for Scoping Reviews. Resultados: se incluyeron 13 estudios que demuestran la importancia de la implicación en la seguridad del paciente y en la prevención de eventos adversos. Sin embargo, se han detectado grietas en la comunicación y fragilidad en la formación de los profesionales, lo que dificulta dicha implicación. El fortalecimiento de la educación en salud, las rondas multidisciplinares y las tecnologías educativas se destacaron como estrategias para ampliar el envolvimiento de los acompañantes. Consideraciones Finales: Este estudio dirige elementos para que profesionales de la salud y gerentes reconsideren el papel de los acompañantes en la seguridad del paciente y desarrollo de estrategias colectivas. Descriptores: Participacón del Paciente; Família; Seguridad del Paciente; Pediatría; Neonatología. 


\section{INTRODUCTION}

The discussion on initiatives to promote safety and quality in health care has been the subject of wide debate worldwide. Patient safety (PS) is understood as the reduction of the risk of unnecessary harm caused by health care through measures that offer better results ${ }^{(1)}$. Thus, patient safety is linked to the adoption of strategies aimed at preventing the occurrence of preventable adverse events (AE) and, when not avoidable, minimize their effects on the patient, in addition to encouraging the adoption of a safety culture, in which errors can be recognized and avoided ${ }^{(1)}$.

Regarding the risk of AE in health care, the World Health Organization (WHO) created the World Alliance for Patient Safety with the aim of improving the quality of health services ${ }^{(2)}$. Therefore, the Ministry of Health, aiming at achieving the WHO goals, implemented the National Patient Safety Program (NPSP) aiming to contribute to safe care in the national territory ${ }^{(3)}$. One of the axes of this program is the "Patient for patient safety", since participation of patients and caregivers during the hospitalization process has been extremely important in increasing PS, as well as in reducing adverse events ${ }^{(2)}$.

The term "patient participation" can be defined as the patient's involvement in the decision-making process in relation to health issues ${ }^{(4)}$. Based on this principle, the aim is to enable patients to know about their health status, whether encouraged to interact with professionals and participate in the decisions of their care plan. Thus, the patient and the companion are encouraged to get involved in care with their rights and singularities respected and, at the same time, collaborate in the prevention of $A E^{(5-6)}$.

Regarding pediatric and neonatology units, children are more exposed to the occurrence of AE because of their specific characteristics. Accelerated metabolism, greater variation in body weight when compared to adults, frequent adjustment of drug doses and concentrations, immaturity in the development of organs and systems, curiosity and unpredictability of movements, characteristics of child development, among other characteristics, make professionals and managers pay special attention to these patients ${ }^{(7-9)}$.

An American study developed by the Institute of Healthcare Improvement identified that, for every 100 children, 40 were victims of $A E$, 18 being potentially preventable ${ }^{(9)}$. In Brazil, a descriptive, cross-sectional observational study found that there were a total of 73 adverse events in the Neonatal and Pediatric Intensive Care Unit, highlighting, among them, losses from the Peripherally Inserted Central Catheter (PICC), phlebitis, skin or soft tissue injury, medication errors, among others ${ }^{(7)}$. In the search for PS and AE prevention, studies emphasize the importance of including companions in patient care, especially in pediatrics and neonatology ${ }^{(10-14)}$. Encouraging the participation of companions in child care favors health education and the co-production of care between them and health professionals ${ }^{(15)}$. However, the literature considers that the family's participation in PS is permeated by many challenges, with different perceptions among the people who participate in the care circumstances, which need to be discussed in search of strategies that lead to a more effective practice $\mathrm{e}^{(16-17)}$.

In order to provide essential information for the creation of strategies aimed at involving the companion in PS and favoring the transposition of scientific evidence on the subject exposed to care practice in neonatology and pediatrics, the following question arose: what does the literature present about evidence on the involvement of companions in PS, from their perspective and that of health professionals in neonatal and pediatric units? It is noteworthy that, in this study, by portraying pediatric and neonatology scenarios, parents, family members or other caregivers were characterized as companions.

This study is justified by obtaining elements that can support discussions on effective strategies in search of greater involvement of the companion in PS in neonatal and pediatric units.

\section{OBJECTIVES}

To describe the scientific evidence on the involvement of companions in patient safety, from their and health professionals' perspective in neonatal and pediatric units.

\section{METHODS}

\section{Ethical aspects}

As this is a scoping review, submission to the Research Ethics Committee was not necessary. However, the reliability and reliability of the information contained in the selected publications was guaranteed ${ }^{(18)}$.

\section{Type of study}

This is a scope review, which aims to identify or explain the main scientific evidence on a certain topic, highlighting existing knowledge gaps, in addition to proposing the clarification of the

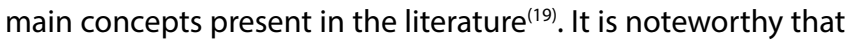
the research was prepared based on the guidelines of the Review Manual of the Joanna Briggs Institute ${ }^{(19)}$.

\section{Methodological Procedure}

This study was registered in the Open Science Framework Platform (https://osf.io/srzvw/), adopting the Preferred Reporting Items for Systematic Reviews and Meta-Analyses extension for Scoping Reviews checklist (PRISMA-ScR) ${ }^{(20)}$, in order to describe the scientific evidence on the involvement of caregivers in patient safety.

Thus, for its development, as mentioned, the recommendations published in the JBI Manual for Evidence Synthesis ${ }^{(19)}$, version 2020, were followed, covering the following steps: defining the objective and research question; define inclusion criteria; define strategy for data selection and extraction; search, selection and analysis of publications in information sources; and presentation and synthesis of results.

The mnemonic population, concept and context (PCC) ${ }^{(19)}$, was used, where P: companions of children and newborns, C: involvement in patient safety and C: pediatric and neonatal hospital units, to create the guiding question: What are the available evidence on companion involvement in pediatric and neonatal patient safety? The inclusion criteria for the pre-selection of studies were: English, Portuguese or Spanish; and publications between 2011 and 2021. Duplicate and review articles, editorials, letters to the editor, abstracts and expert opinion or articles that did not meet the purpose of this review were considered as exclusion criteria. 


\section{Data collect}

The next steps (extraction, creation and search of evidence) correspond to the research strategy and were reported in a comprehensive manner, in accordance with the JBI recommendations. The search was carried out between July 2020 and April 2021, in the Latin American and Caribbean Literature in Health Science (LILACS) database, nursing database (BDENF) Medical Literature Analysis and Retrieval System Online (MEDLINE) access via PubMed, Cochrane Library, CINAHL, SCOPUS, Web of Science and EMBASE. Appropriate descriptors were chosen for the researched databases (Medical Subject Headings - MeSH and Descriptors in Health Sciences - DeCS), as well as keywords were adopted in order to expand the textual research. Furthermore, the reference list of the articles included was used, in order to verify the articles used and retrieve the pertinent ones. Chart 1 demonstrates the strategies developed using the descriptors listed with the help of the Boolean operators AND and OR, in addition to the quantity of articles located and selected in each database.

It should be noted that two more articles were included in the reference list, totaling 13 articles in the sample.

\section{Data analysis}

The study selection was performed through careful reading of titles and abstracts, in order to verify if the studies fit in the final selection, meeting the aforementioned criteria. For the final selection, articles that presented evidence on the involvement of the companion in pediatric and neonatal patient safety were chosen. Data collection and analysis were performed by three independent reviewers and, when consensus was not possible, the evaluation of a fourth reviewer was used. The final stages of extraction and delimitation of information related to the evidence were carried out through descriptive analysis to characterize the studies. This step was performed using an instrument developed by the authors, consisting of the characterization of the publication (year, publication country, title and authors), methodological characteristics (study design, scenario and sample), main results and level of evidence of the study. The classification regarding the level of evidence was based on the categorization of the Agency for Healthcare Research and Quality (AHRQ), which proposes seven levels of evidence, 1 being the highest level and 7 the lowest level of evidence ${ }^{(21)}$.

Chart 1 - Search strategies and number of studies located and selected in databases, Belo Horizonte, Minas Gerais, Brazil, 2021

\begin{tabular}{|c|c|c|}
\hline $\begin{array}{l}\text { Database } \\
\text { (Number of studies) }\end{array}$ & Search Strategies & $\begin{array}{l}\text { Included } \\
\text { study }\end{array}$ \\
\hline $\begin{array}{l}\text { LILACS } \\
(22)\end{array}$ & $\begin{array}{l}\text { "Patient Safety" OR"Seguridad del Paciente" OR"Segurança do Paciente") AND ("Medical Chaperones" OR } \\
\text { "Chaperones Médicos" OR"Acompanhantes Formais em Exames Físicos" OR"Acompanhante Formal do Paciente" } \\
\text { OR"Acompanhante Médico" OR"Acompanhante de Paciente" OR"Acompanhantes Formais de Pacientes" OR } \\
\text { "Acompanhantes de Pacientes" OR"Apoio Familiar de Paciente" OR"caregivers" OR"cuidadores" OR"cuidador" OR } \\
\text { "Cuidador Familiar" OR"Cuidador de Família" OR"Cuidadores Familiares" OR"Cuidadores de Família" OR"Familiar } \\
\text { Cuidador" OR"Familiares Cuidadores" OR"Participação da Família" OR"Participação Familiar" OR"Family Participation" } \\
\text { OR"Envolvimento da Família" OR"Envolvimento Familiar" OR"Family Involvement" OR"Engajamento da Família" } \\
\text { OR"Engajamento Familiar" OR"Family Engagement" OR"envolvimento" OR"involvement" OR"engajamento" OR } \\
\text { "engagement" OR"acompanhante" OR"companion") AND ("pediatrics" OR"pediatria" OR"pediatria" OR"child" OR } \\
\text { "niño" OR"criança" OR"crianças" OR"Paciente Pediátrico" OR"Pediatric Patient"). }\end{array}$ & 1 \\
\hline $\begin{array}{l}\text { BDENF } \\
(10)\end{array}$ & $\begin{array}{l}\text { ("Patient Safety" } O R \text { "Seguridad del Paciente" OR "Segurança do Paciente") AND ("Medical Chaperones" OR } \\
\text { "Chaperones Médicos» } O R \text { «Acompanhantes Formais em Exames Físicos" OR "Acompanhante Formal do Paciente" } \\
\text { OR "Acompanhante Médico" OR "Acompanhante de Paciente" OR "Acompanhantes Formais de Pacientes" OR } \\
\text { "Acompanhantes de Pacientes" OR "Apoio Familiar de Paciente" OR "caregivers" OR "cuidadores" OR "cuidador" } \\
\text { OR "Cuidador Familiar" OR "Cuidador de Família" OR "Cuidadores Familiares" OR "Cuidadores de Família" OR } \\
\text { "Familiar Cuidador" OR "Familiares Cuidadores" OR "Participação da Família" OR "Participação Familiar" OR } \\
\text { "Family Participation" OR "Envolvimento da Família" OR "Envolvimento Familiar" OR "Family Involvement" OR } \\
\text { "Engajamento da Família" OR "Engajamento Familiar" OR "Family Engagement" OR "envolvimento" OR "involvement" } \\
\text { OR "engajamento" OR "engagement" OR "acompanhante" OR "companion") AND ("pediatrics" OR "pediatria" OR } \\
\text { "pediatria" OR "child" OR "niño" OR "criança" OR "crianças" OR "Paciente Pediátrico" OR "Pediatric Patient"). }\end{array}$ & 2 \\
\hline $\begin{array}{l}\text { MEDLINE via PubMed } \\
(908)\end{array}$ & $\begin{array}{l}\text { "patient safety AND medical chaperones OR caregivers OR family participation OR family involvement OR family } \\
\text { engagement OR involvement OR engagement OR compa]nion AND pediatrics OR child OR pediatric patient". }\end{array}$ & 6 \\
\hline $\begin{array}{l}\text { COCHRANE } \\
(163)\end{array}$ & $\begin{array}{l}\text { "patient safety AND medical chaperones OR caregivers OR family participation OR family involvement OR family } \\
\text { engagement OR involvement OR engagement OR companion AND pediatrics OR child OR pediatric patient". }\end{array}$ & 0 \\
\hline $\begin{array}{l}\text { CINAHL } \\
(204)\end{array}$ & $\begin{array}{l}\text { "patient safety AND medical chaperones OR caregivers OR family participation OR family involvement OR family } \\
\text { engagement OR involvement OR engagement OR companion AND pediatrics OR child OR pediatric patient". }\end{array}$ & 0 \\
\hline $\begin{array}{l}\text { SCOPUS } \\
(459)\end{array}$ & $\begin{array}{l}\text { "patient safety AND medical chaperones OR caregivers OR family participation OR family involvement OR } \\
\text { family engagement OR companion AND pediatric patient". }\end{array}$ & 2 \\
\hline $\begin{array}{l}\text { WEB OF SCIENCE } \\
(15)\end{array}$ & $\begin{array}{l}\text { "patient safety AND medical chaperones OR caregivers OR family participation OR family involvement OR family } \\
\text { engagement OR involvement OR engagement OR companion AND pediatrics OR child OR pediatric patient". }\end{array}$ & 0 \\
\hline $\begin{array}{l}\text { EMBASE } \\
(711)\end{array}$ & "patient safety AND family OR caregiver AND pediatric patient". & 0 \\
\hline TOTAL* & & 11 \\
\hline
\end{tabular}


Then, a thematic analysis of the content was carried out to identify the key posts in the literature found, which were grouped into guiding axes. Finally, the results were reviewed in relation to the involvement of companions in the safety of pediatric and neonatal patients, especially with regard to facilitating and hindering aspects, as well as the strategies of involvement of the companion in patient safety.

\section{RESULTS}

A total of 2651 studies were found in the databases, 2 were identified in the reference lists. From the first analysis, 66 studies were removed for duplication, totaling 2587 for title and abstract reading. Subsequently, the three reviewers independently verified those who answered the research question or who were within the topic, with the selection of articles proper for reading the full text, with 2431 studies being excluded, resulting in articles eligible for reading. Of these, 143 were analyzed according to the inclusion criteria. Therefore, 13 articles met the inclusion criteria and were part of the final sample (Figure 1).

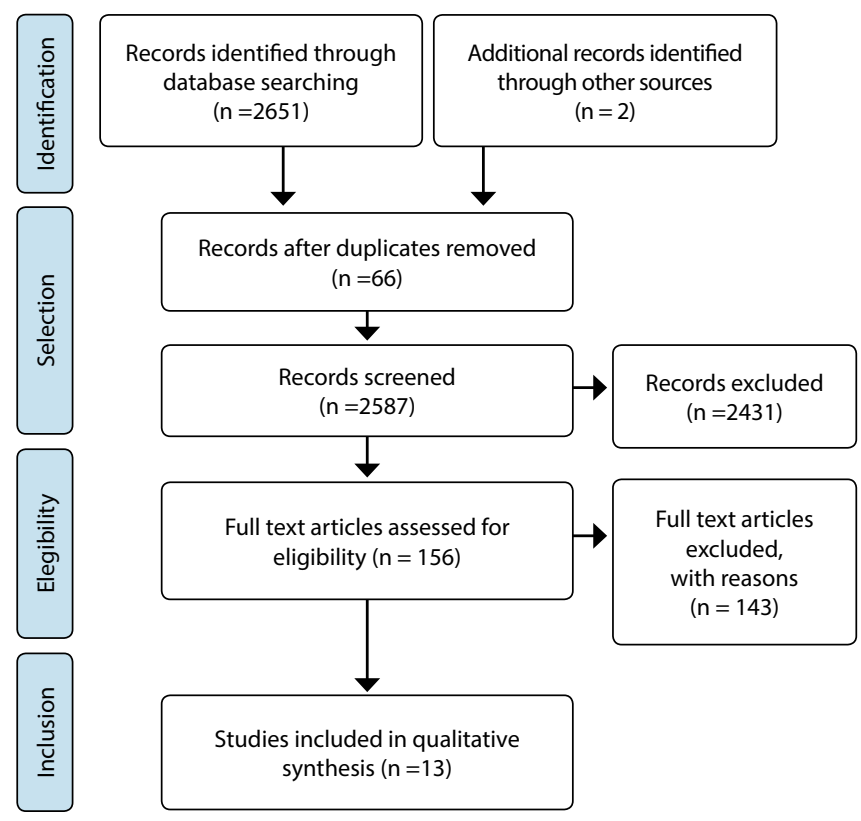

Figure 1 - Flowchart of the review article selection process, PRISMA-ScR, Belo Horizonte, Minas Gerais, Brazil, 2021
The final sample consisted of a total of 13 articles, among which the oldest was published in 2014 and the most recent in 2020. Three (23.1\%) were published in 2020, two (15.4\%) in 2019, two (15.4\%) in 2018, three (23.1\%) in 2017 and three (23.1\%) in 2014.

The most frequent design was qualitative, with ten (76.9\%) articles, followed by quantitative, with two (15.4\%), and one (7.7\%) characterized as a mixed method. The studies included in the review are presented in Chart 2 with information on authors, title, year, country of publication, objective, design, sample, scenario, results and level of evidence.

Thus, to facilitate the presentation of the information extracted from the records, the contents were grouped into four guiding axes: perception of the involvement of companions in patient safety, facilitating aspects, hindering aspects and strategies to increase the involvement of companions in the patient safety (Chart 3).

\section{DISCUSSION}

This study contributed to investigations on the involvement of companions in PS in pediatric and neonatal units from the perspective of those and health professionals. The results obtained showed points of divergence and agreement in relation to professionals and companions regarding the perception, strategies used, facilitating and hindering aspects for the involvement of companions in patient safety.

Regarding the perception of the involvement of companions in PS, they recognized that they can contribute to patient safety, especially in the prevention of incidents and $A E^{(23,25,29)}$, in addition to stressing that this participation should be mandatory ${ }^{(25)}$, diverging from the professionals' perception ${ }^{(33)}$. However, professionals say that companions, as long as they are oriented and aware of their participation, can positively influence PS. They also reinforce the need for interaction, dialogue and clear communication between professionals and companions s $^{(23,33)}$. This is a very important aspect, considering that companions recognize that the lack of attention and support from professionals to the observations made by them, related to the children health and safety, contributes to increased anxiety, insecurity and even from stress, causing distancing instead of approximation ${ }^{(29-30)}$.

Chart 2 - Characteristics of the studies included in the scoping review, Belo Horizonte, Minas Gerais, Brazil, 2021

\begin{tabular}{|c|c|c|c|c|c|}
\hline $\begin{array}{l}\text { Author } \\
\text { Title }\end{array}$ & $\begin{array}{c}\text { Year } \\
\text { Country }\end{array}$ & Objective & $\begin{array}{l}\text { Study design } \\
\text { Sample } \\
\text { Scenario }\end{array}$ & Results & $\begin{array}{l}\text { Level of } \\
\text { evidence }\end{array}$ \\
\hline $\begin{array}{l}\text { Biasibetti et al. }{ }^{(22)} \\
\text { "Comunicação } \\
\text { para a segurança } \\
\text { do paciente } \\
\text { em internações } \\
\text { pediátricas" }\end{array}$ & $\begin{array}{l}2019 \\
\text { Brazil }\end{array}$ & $\begin{array}{l}\text { To analyze the } \\
\text { perception of health } \\
\text { professionals and } \\
\text { companions/family } \\
\text { members regarding } \\
\text { the development } \\
\text { of communication } \\
\text { for patient safety } \\
\text { in pediatric } \\
\text { hospitalizations. }\end{array}$ & $\begin{array}{l}\text { Type of study: } \\
\text { Qualitative. } \\
\text { Sample: } \\
44 \text { health professionals } \\
\text { and } 94 \text { companions. } \\
\text { Scenario: } \\
\text { Pediatric clinical-surgical } \\
\text { inpatient units. }\end{array}$ & $\begin{array}{l}\text { Participants identified problems in the academic } \\
\text { training of health professionals, failures in } \\
\text { institutional organization, lack of professional } \\
\text { commitment and lack of integration between the } \\
\text { health team and companions. As for the tools to } \\
\text { qualify communication, the participants pointed } \\
\text { out strategies such as the organization and } \\
\text { compliance with standardized, computerized and } \\
\text { bureaucratic processes, as well as the participation } \\
\text { of all actors involved in care for the development } \\
\text { of improvements related to pediatric patient safety } \\
\text { through of effective communication. }\end{array}$ & 6 \\
\hline
\end{tabular}


Chart 2

\begin{tabular}{|c|c|c|c|c|c|}
\hline $\begin{array}{l}\text { Author } \\
\text { Title }\end{array}$ & $\begin{array}{c}\text { Year } \\
\text { Country }\end{array}$ & Objective & $\begin{array}{l}\text { Study design } \\
\text { Sample } \\
\text { Scenario }\end{array}$ & Results & $\begin{array}{l}\text { Level of } \\
\text { evidence }\end{array}$ \\
\hline $\begin{array}{l}\text { Corbaly et al. }{ }^{(23)} \\
\text { "Parental } \\
\text { involvement in } \\
\text { the preoperative } \\
\text { surgical safety } \\
\text { checklist is } \\
\text { welcomed by both } \\
\text { parents and staff" }\end{array}$ & $\begin{array}{l}2014 \\
\text { Ireland }\end{array}$ & $\begin{array}{l}\text { To establish how } \\
\text { the surgical team } \\
\text { and parents accept } \\
\text { parental involvement } \\
\text { during the Safe } \\
\text { Surgery Checklist. }\end{array}$ & $\begin{array}{l}\text { Type of study: } \\
\text { Qualitative. } \\
\text { Sample: } \\
42 \text { parents and } 42 \\
\text { professionals. } \\
\text { Scenario: } \\
\text { Mother and child } \\
\text { hospital. }\end{array}$ & $\begin{array}{l}\text { Parents feel that family participation during the } \\
\text { safe surgery checklist should be mandatory. } \\
\text { The healthcare team recognized that parental } \\
\text { participation is important to promote patient } \\
\text { safety. }\end{array}$ & 6 \\
\hline $\begin{array}{l}\text { Gonçalves et al. }{ }^{(24)} \\
\text { "Estratégia lúdica } \\
\text { para promoção do } \\
\text { engajamento de pais } \\
\text { e acompanhantes } \\
\text { na segurança do } \\
\text { paciente pediátrico" }\end{array}$ & $\begin{array}{l}2020 \\
\text { Brazil }\end{array}$ & $\begin{array}{l}\text { To evaluate a playful } \\
\text { strategy developed } \\
\text { to promote the } \\
\text { engagement } \\
\text { of parents and } \\
\text { companions in } \\
\text { pediatric patient } \\
\text { safety actions. }\end{array}$ & $\begin{array}{l}\text { Type of study: } \\
\text { Qualitative. } \\
\text { Sample: } \\
17 \text { parents and } \\
\text { companions. } \\
\text { Scenario: } \\
\text { Pediatric inpatient unit. }\end{array}$ & $\begin{array}{l}\text { Participants evaluated the game as a playful, } \\
\text { innovative, informative and educational } \\
\text { resource regarding the process of family } \\
\text { involvement in patient safety. Furthermore, they } \\
\text { highlighted the change in behavior in favor of } \\
\text { patient safety after experiencing the game. }\end{array}$ & 6 \\
\hline $\begin{array}{l}\text { Hoffman et al. }{ }^{(25)} \\
\text { "Identificação } \\
\text { de incidentes de } \\
\text { segurança do } \\
\text { paciente pelos } \\
\text { acompanhantes } \\
\text { de crianças } \\
\text { hospitalizadas" }\end{array}$ & $\begin{array}{l}2019 \\
\text { Brazil }\end{array}$ & $\begin{array}{l}\text { Describe the security } \\
\text { incidents identified } \\
\text { by the companions of } \\
\text { hospitalized children. }\end{array}$ & $\begin{array}{l}\text { Type of study: } \\
\text { Qualitative. } \\
\text { Sample: } \\
40 \text { companions. } \\
\text { Scenario: } \\
\text { Pediatric Inpatient Units. }\end{array}$ & $\begin{array}{l}\text { The incidents identified by the companions } \\
\text { were related to falls, identification, dietary } \\
\text { errors, medication errors, hygiene and } \\
\text { communication failures. }\end{array}$ & 6 \\
\hline $\begin{array}{l}\text { Hoffman et al.(26) } \\
\text { "Patient safety } \\
\text { incidents reported } \\
\text { by relatives of } \\
\text { hospitalized } \\
\text { children" }\end{array}$ & 2020 & $\begin{array}{l}\text { To know the main } \\
\text { safety incidents } \\
\text { reported by family } \\
\text { members of patients } \\
\text { admitted to pediatric } \\
\text { units. }\end{array}$ & $\begin{array}{l}\text { Type of study: } \\
\text { Qualitative. } \\
\text { Sample: } \\
91 \text { family members. } \\
\text { Scenario: } \\
\text { Intensive care unit } \\
\text { Pediatrics and Pediatric } \\
\text { Emergency Room. }\end{array}$ & $\begin{array}{l}\text { Family members recognized incidents related } \\
\text { to medication administration, communication } \\
\text { failures, incorrect hand hygiene, incorrect use } \\
\text { of Personal Protective equipment, failures in } \\
\text { patient identification and monitoring of visits. }\end{array}$ & 6 \\
\hline $\begin{array}{l}\text { Khan et al. }{ }^{(27)} \\
\text { "Families as partners } \\
\text { in hospital error } \\
\text { and adverse event } \\
\text { surveillance" }\end{array}$ & $\begin{array}{l}2017 \\
\text { United } \\
\text { States }\end{array}$ & $\begin{array}{l}\text { Perform comparison of } \\
\text { adverse events records: } \\
\text { 1)With the presence } \\
\text { and report of the family } \\
\text { and without the family; } \\
\text { 2)Reported by family } \\
\text { and physicians; } \\
\text { 3)Reported by the } \\
\text { family and rate } \\
\text { established by the } \\
\text { hospital. }\end{array}$ & $\begin{array}{l}\text { Type of study: } \\
\text { Quantitative. } \\
\text { Sample: } \\
717 \text { companions and } \\
77 \text { nursing and medical } \\
\text { residents. } \\
\text { Scenario: } \\
\text { Pediatric units. }\end{array}$ & $\begin{array}{l}\text { 1)The rates of adverse events reported in the } \\
\text { presence of family members were } 1.1 \text { times } \\
\text { higher than rates without family members. } \\
\text { 2) Families and physicians reported similar error } \\
\text { rates ( } 10.0 \text { vs } 12.8 \text { per } 1000 \text { patient-days; and } \\
\text { AEs ( } 8.5 \text { vs } 6.2 \text { per } 1000 \text { patient-days). } \\
\text { 3) Family-reported error rates were } 5.0 \text { times } \\
\text { higher than adverse events rates reported by } \\
\text { hospital incident reports. }\end{array}$ & 4 \\
\hline $\begin{array}{l}\text { Lydon et al. }{ }^{(28)} \\
\text { "Parents' } \\
\text { perspectives on } \\
\text { safety in neonatal } \\
\text { intensive care: a } \\
\text { mixed-methods } \\
\text { study" }\end{array}$ & $\begin{array}{l}2014 \\
\text { United } \\
\text { States }\end{array}$ & $\begin{array}{l}\text { To examine parents' } \\
\text { perspectives } \\
\text { regarding the safety } \\
\text { of the } \\
\text { patient in the } \\
\text { Neonatal Intensive } \\
\text { Care Unit. }\end{array}$ & $\begin{array}{l}\text { Type of study: } \\
\text { Qualitative and } \\
\text { quantitative. } \\
\text { Sample: } \\
46 \text { parents responded } \\
\text { to the questionnaires } \\
\text { and } 14 \text { of these parents } \\
\text { also participated in } 10 \\
\text { interviews. } \\
\text { Scenario: } \\
\text { Neonatal Intensive Care. }\end{array}$ & $\begin{array}{l}\text { Parents showed little concern about the safety } \\
\text { of the procedures. Therefore, participants } \\
\text { suggested engagement strategies that address } \\
\text { clinical treatment articulated to the domains of } \\
\text { physical, developmental and emotional safety, } \\
\text { which may result in safety improvements. }\end{array}$ & 6 \\
\hline
\end{tabular}


Chart 2 (concluded)

\begin{tabular}{|c|c|c|c|c|c|}
\hline $\begin{array}{l}\text { Author } \\
\text { Title }\end{array}$ & $\begin{array}{c}\text { Year } \\
\text { Country }\end{array}$ & Objective & $\begin{array}{l}\text { Study design } \\
\text { Sample } \\
\text { Scenario }\end{array}$ & Results & $\begin{array}{l}\text { Level of } \\
\text { evidence }\end{array}$ \\
\hline $\begin{array}{l}\text { Massa et al. }{ }^{(29)} \\
\text { "Condiciones de } \\
\text { seguridad percibidas } \\
\text { por cuidadores } \\
\text { familiares en } \\
\text { atención pediátrica" }\end{array}$ & $\begin{array}{c}2020 \\
\text { Colombia }\end{array}$ & $\begin{array}{l}\text { To identify the } \\
\text { perception of } \\
\text { caregivers about the } \\
\text { safety conditions of } \\
\text { care in a pediatric } \\
\text { hospital. }\end{array}$ & $\begin{array}{l}\text { Type of study: } \\
\text { Quantitative. } \\
\text { Sample: } \\
163 \text { caregivers. } \\
\text { Scenario: } \\
\text { Pediatric Units. }\end{array}$ & $\begin{array}{l}86 \% \text { of caregivers perceived safety in the } \\
\text { child's hospitalization and, according to } \\
\text { them, } 60.2 \% \text { of professionals explained the } \\
\text { procedures to caregivers. Communication } \\
\text { is clear for } 70 \% \text { of caregivers, } 58.3 \% \text { of them } \\
\text { are alert to detect possible risks, } 75.5 \% \text { follow } \\
\text { the recommendations given and } 70.5 \% \text { of } \\
\text { caregivers trust the professionals. }\end{array}$ & 6 \\
\hline $\begin{array}{l}\text { Peres et al. }{ }^{(30)} \\
\text { "Percepção de } \\
\text { familiares e } \\
\text { cuidadores quanto } \\
\text { à segurança } \\
\text { do paciente } \\
\text { em unidades } \\
\text { de internação } \\
\text { pediátrica" }\end{array}$ & $\begin{array}{l}2018 \\
\text { Brazil }\end{array}$ & $\begin{array}{l}\text { To recognize the } \\
\text { perceptions of } \\
\text { family members and } \\
\text { companions regarding } \\
\text { patient safety in a } \\
\text { pediatric inpatient } \\
\text { unit. }\end{array}$ & $\begin{array}{l}\text { Type of study: } \\
\text { Qualitative. } \\
\text { Sample: } \\
24 \text { companions. } \\
\text { Scenario: } \\
\text { Pediatric Inpatient Units. }\end{array}$ & $\begin{array}{l}\text { Several respondents have never heard of } \\
\text { patient safety. Family members believe that } \\
\text { their main role is to provide emotional support } \\
\text { for the child, but they recognize that they } \\
\text { can help to prevent mistakes. Adverse events } \\
\text { related to medication, procedure and lack } \\
\text { of communication are the most worrying of } \\
\text { parents. }\end{array}$ & 6 \\
\hline $\begin{array}{l}\text { Rodrigues et al. } \\
\text { "Segurança do } \\
\text { paciente em } \\
\text { unidade neonatal: } \\
\text { preocupações } \\
\text { e estratégias } \\
\text { vivenciadas por pais" }\end{array}$ & $\begin{array}{l}2018 \\
\text { Brazil }\end{array}$ & $\begin{array}{l}\text { To analyze how } \\
\text { parents identify } \\
\text { patient safety in a } \\
\text { neonatal unit. }\end{array}$ & $\begin{array}{l}\text { Type of study: } \\
\text { Qualitative. } \\
\text { Sample: } \\
23 \text { family members. } \\
\text { Scenario: } \\
\text { Neonatal inpatient unit. }\end{array}$ & $\begin{array}{l}\text { The parents spoke about patient safety, } \\
\text { mentioning their concerns regarding the flow } \\
\text { of people, inefficient communication, problems } \\
\text { with patient identification, the risk of infection, } \\
\text { the risk of falling and injury due to the use of } \\
\text { a medical device, and strategies that could } \\
\text { prevent these incidents. }\end{array}$ & 6 \\
\hline $\begin{array}{l}\text { Rosenberg et al. }{ }^{(32)} \\
\text { "Provider } \\
\text { perspectives } \\
\text { on partnering } \\
\text { with parents } \\
\text { of hospitalized } \\
\text { children to improve } \\
\text { safety" }\end{array}$ & $\begin{array}{l}2017 \\
\text { United } \\
\text { States }\end{array}$ & $\begin{array}{l}\text { To explore the } \\
\text { perspectives and } \\
\text { experiences of } \\
\text { pediatric professionals } \\
\text { regarding family } \\
\text { participation in } \\
\text { pediatric patient } \\
\text { safety. }\end{array}$ & $\begin{array}{l}\text { Type of study: } \\
\text { Qualitative. } \\
\text { Sample: } \\
20 \text { health professionals. } \\
\text { Scenario: } \\
\text { Pediatric teaching } \\
\text { hospital. }\end{array}$ & $\begin{array}{l}\text { Professionals believe that parental involvement } \\
\text { should not be mandatory, but that it helps to } \\
\text { reduce errors. They presented, as facilitating } \\
\text { aspects for patient safety, the clear definition of } \\
\text { roles, the gain of trust, sympathy and effective } \\
\text { communication. As barriers, they mentioned } \\
\text { role conflicts, the lack of skill and time to put } \\
\text { parents in safety, in addition to the concern with } \\
\text { overloading the family. }\end{array}$ & 6 \\
\hline $\begin{array}{l}\text { Silva et al. }{ }^{(33)} \\
\text { "Segurança } \\
\text { da criança } \\
\text { hospitalizada na UTI: } \\
\text { compreendendo os } \\
\text { eventos adversos } \\
\text { sob a ótica do } \\
\text { acompanhante" }\end{array}$ & $\begin{array}{l}2014 \\
\text { Brazil }\end{array}$ & $\begin{array}{l}\text { To describe the } \\
\text { adverse events } \\
\text { identified by the } \\
\text { family member/ } \\
\text { caregiver in a Pediatric } \\
\text { Intensive Care Unit. }\end{array}$ & $\begin{array}{l}\text { Type of study: } \\
\text { Qualitative. } \\
\text { Sample: } \\
13 \text { companions. } \\
\text { Scenario: } \\
\text { Pediatric Intensive Care } \\
\text { Unit. }\end{array}$ & $\begin{array}{l}\text { The family member/caregiver realized that } \\
\text { many of the adverse events were related to } \\
\text { a lack of scientific knowledge on the part } \\
\text { of the nursing team to safely perform some } \\
\text { procedures. Regarding the medical team, there } \\
\text { were problems related to communication with } \\
\text { family members/caregivers, especially the form } \\
\text { and content of the information received. }\end{array}$ & 6 \\
\hline $\begin{array}{l}\text { Sousa et al. }{ }^{(34)} \\
\text { "A participação da } \\
\text { família na segurança } \\
\text { do paciente em } \\
\text { unidades neonatais } \\
\text { na perspectiva do } \\
\text { enfermeiro" }\end{array}$ & $\begin{array}{l}2017 \\
\text { Brazil }\end{array}$ & $\begin{array}{l}\text { To understand } \\
\text { family participation } \\
\text { in patient safety in } \\
\text { Neonatal Intensive } \\
\text { Care Units from the } \\
\text { perspective of nurses. }\end{array}$ & $\begin{array}{l}\text { Type of study: } \\
\text { Qualitative. } \\
\text { Sample: } \\
14 \text { nurses. } \\
\text { Scenario: } \\
\text { Intermediate Care and } \\
\text { Neonatal Intensive Care } \\
\text { Unit. }\end{array}$ & $\begin{array}{l}\text { Nurses recognize the importance of family } \\
\text { participation in neonatal patient safety, as well } \\
\text { as in the prevention of incidents. However, they } \\
\text { highlighted the lack of preparation to deal with } \\
\text { the family member in their daily work. They also } \\
\text { highlighted that the welcoming and guidance } \\
\text { of family members are important strategies for } \\
\text { family involvement in patient safety actions. }\end{array}$ & 6 \\
\hline
\end{tabular}

Chart 3 - Analysis of the involvement of companions in patient safety, from their and health professionals' perspective, Belo Horizonte, Minas Gerais, Brazil, 2021

Perception about the involvement of companions in patient safety

\begin{tabular}{|l|l|}
\hline Perspective of companions & Perspective of health professionals
\end{tabular}

- Companion as a barrier to the occurrence of adverse events ${ }^{(23,25,29)}$;

- Participation of companions contributes to patient safety and should be mandatory ${ }^{(24)}$;

- Participation of companions does not predispose to increased anxiety $^{(24)}$. 
Facilitating aspects for the involvement of companions in patient safety

\section{Perspective of companions}

- Receive explanations about the rules and procedures offered by the team $^{(30)}$;

- Having clear communication with the health team ${ }^{(30)}$;

- Receive information about risks, complications and procedures performed ${ }^{(30)}$;

- Receive support and attention from the team when identifying risks for adverse events ${ }^{(30)}$

- Trust professionals ${ }^{(29-30)}$.

- Be aware of the responsibility of companions in monitoring the care provided to their children ${ }^{(29,31)}$;

- Enable companions to identify risks and adverse events ${ }^{(26-27,30-32)}$.

Hindering aspects for the involvement of companions in patient safety

\section{Hindering aspects for the involvement of companions in patient safety}

Perspective of companions

- Realize that there are difficulties in reporting patient safety incidents in a form or computerized system ${ }^{(23)}$;

- Ineffective communication between all those involved in child care $^{(23,27,29,32)}$;

- Lack of sufficient materials and equipment, as well as the precariousness of the hospital structure ${ }^{(26)}$;

- Impact of the Neonatal Intensive Care Unit environment on the bonding process between the child and companions ${ }^{(29)}$;

- Lack of knowledge of how to help prevent health risks ${ }^{(30)}$;

- Unfamiliarity of the patient/companion's rights and duties ${ }^{(30)}$;

- Companions feel excluded from the child's treatment, diagnosis and prognosis, becoming more anxious and insecure ${ }^{(34)}$;

- Unfamiliarity about the term patient safety ${ }^{(31)}$.

\section{Strategies for the involvement of companions in patient safety}

\section{Perspective of companions}

- Games and playful activities that address the subject of patient safety ${ }^{(25)}$;

- Effective communication between everyone involved in child care ${ }^{(23,32)}$;

- Adoption of practices against adverse events with the participation of companions $^{(26,29,31)}$;

- Professional qualification through continuing education and encouraging research in the area of patient safety ${ }^{(31,34)}$.

\section{Perspective of health professionals}

- Participation of companions in the safe surgery checklist does not change the procedure time ${ }^{(24)}$.

- Recognition of the importance of the participation of companions during the safe surgery checklist ${ }^{(24)}$;

- Family recognition as a barrier to preventing adverse events ${ }^{(23)}$.

\section{Perspective of health professionals}

- Ineffective communication between everyone involved ${ }^{(23,33)}$;

- Feeling of incapacity on the part of professionals to deal with companions s $^{(33)}$;

- Absence or distraction of some companions $s^{(33) \text {; }}$

- Concern of professionals with overloading companions ${ }^{(33)}$.
Professionals believe that involvement depends on the professional attitude of encouraging companions, as well as their desire to participate ${ }^{(33)}$. The health team also argues that the lack of skills, training, time to introduce companions to safety, and the concern with the increase in work demand are limiting aspects in this process. Another reported point concerns the absence of a companion at many times and the conflict of roles that may exist between companions and professionals, which cause wear on both parties, often unnecessary, directly interfering with the quality of care and patient safety ${ }^{(18,33)}$.

The companions also mentioned the importance of recognizing risk situations for AEs, especially in relation to medication errors, patient identification ${ }^{(26-27,30-31)}$ and care procedures ${ }^{(27,30-32)}$. Among the incidents recognized by companions, there are delays in administration, poor communication related to therapy, mistake in drug suspension, infusion time and incorrect dosages, and lack of an allergy bracelet ${ }^{(27)}$. Studies show that, in pediatrics, many AE could be minimized or prevented in face of a partnership and effective communication with the family ${ }^{(30,33-36)}$. The companion has the right to be informed about the medications in use, being able to pay attention to some aspects, such as checking the right medication for the child, at the

\section{Perspective of health professionals}

- Exchange of information between professionals through systematic shift change, multidisciplinary rounds, transfer of care between sectors and regular team meetings with the inclusion of companions ${ }^{(23)}$;

- Integration of the care team with companions ${ }^{(23)}$;

- Practice of double checking information with companions ${ }^{(23)}$;

- Creation of training and ongoing education to train the team in the process of including companions in patient care and safety ${ }^{(23)}$. right time, in addition to monitoring and clarifying doubts with a professional during the administration of the medication ${ }^{(37-38)}$. Therefore, the importance of the companions' participation in the prevention of medication errors is perceived, in order to effectively contribute to the quality of health care and in the $\mathrm{PS}(39)$.

With regard to the patient identification protocol, parents or guardians should receive information, at the time of placing the bracelets, about the importance of their use and the need for maintenance and verification of data. Thus, a study warns that only $35 \%$ of parents or guardians were informed about the importance of using an identification bracelet, which motivates the discussion about the need for companions to receive information so that they can be co-participants in the care, contributing to the safety of the neonatal care ${ }^{(40)}$.

Regarding the incidents detected by companions related to care procedures, failures in care with probes, incorrect disposal of materials, delays in forwarding exams and surgical procedures, incorrect handling of catheters, among others, were identified ${ }^{(27)}$. These incidents pointed out by the companions reveal possible flaws in the follow-up records, highlighting the importance of family involvement not only in prevention, but also in the 
evaluation process of care procedures. To enable the companion's involvement in the child's safety, it is necessary for professionals to improve the instrumentation of caregivers through education and in the documentation of records in medical records ${ }^{(39)}$.

Other AEs identified by companions were risk of infections $^{(26-27,30,32)}$, phlebitis ${ }^{(30)}$, falls or risk of falling ${ }^{(26,27,30-31)}$, pressure injury $^{(30)}$, lack of control of access to the unit ${ }^{(27,32)}$, failures in the unit's routine and team dynamics ${ }^{(32)}$, errors in the diet offered to patients ${ }^{(26-27)}$ and unidentified isolation beds ${ }^{(26)}$. These situations reinforce the importance of involving companions as partners in the prevention of $A E$ and, consequently, of PS ${ }^{(23)}$. Thus, there is a growing concern of health and teaching institutions with the PS policy, which includes investment in bringing the companion closer to the care being provided, making them co-responsible and partners for the prevention of failures and damage, with increment of the possibilities of a safe hospitalization ${ }^{(40)}$.

Another relevant aspect in the findings is related to the participation of the companion during the safe surgery checklist. For the professionals, the presence of companions during the checklist has been a very valuable experience, as it provides opportunities for interaction, dialogue and listening ${ }^{(24)}$. The authors state that trust in professionals ${ }^{(29-30)}$ and clear communication between professionals and companions are determining factors for involvement. "Clear communication" is understood as receiving explanations about the rules and procedures offered by the health team and information about risks, complications and procedures performed ${ }^{(30)}$. Communication reveals itself as one of the main points of attention regarding the effectiveness of the companions' involvement in PS.

Therefore, although studies point out multiple factors that favor the distancing of companions during the care process, it is noted that communication goes beyond all these spheres. Communication failures are identified by both professionals and companions, and it may occur within the team, as in situations of misunderstanding between professionals, high staff turnover, bureaucracy in filling out medical records and side conversations during the shift change. The lack of scientific knowledge on the part of companions can generate dependence on providing specific information in a clear and objective way $^{(23,27,29,32-33)}$. Thus, the strategies to promote the involvement of the companion are very much based on improving communication.

As a tool to qualify the communication process, especially among professionals, it is important to double check the information, including the companion. This practice of checking is recommended from dispensing the drug at the pharmacy to administering it to the patient. Double verification can be a strategy that promotes communication between professionals, being proposed to avoid greater risks of $\mathrm{AE}^{(22)}$.

The frequent exchange of information between professionals, through systematic and judicious shift change, multidisciplinary rounds, transfer of care between sectors and regular team meetings, can also increase the safety of hospitalized patients. For this practice to be incorporated and continued in care, factors such as multidisciplinary and the aptitude of professionals can be implemented. In addition to these, it is recommended to avoid parallel conversations, interruptions in the method, as well as early entries and exits ${ }^{(22)}$.

Another strategy refers to playful games, which are tools increasingly used to provide information in a simple way. These games, in addition to bringing professionals closer to companions, favor distraction and relaxation, as the hospital environment is extremely stressful ${ }^{(24,41-42)}$.

Health education is also a relevant plan for the training of health professionals with regard to the focus of objective communication. As a form of educational strategy, members of the multidisciplinary team suggest that training be carried out within the service, with a focus on patient safety ${ }^{(22)}$. This strategy is not only related to the failure of communication, but also usefully covers the correct hand hygiene, proceeding properly in the use of procedure gloves and in the use of individual and collective protective equipment, which if used, when applied, incorrectly affect the PS ${ }^{(25)}$. The use of computerized methodologies has also been considered as a strategy to improve communication between health professionals ${ }^{(22)}$.

Furthermore, an environment conducive to conflict resolution is critical to promoting safer care. The companions also pointed out that clearer communication with health professionals leads to better instruction to participate in the care, preserving possible risks to the child's health ${ }^{(22)}$.

Another study infers that the inclusion of companions in the child's general care is important, especially in the surveillance of patient safety ${ }^{(26)}$. This surveillance expands the detection of errors committed by health professionals. Therefore, giving voice to companions and listening to reports can increase the quality and safety of care for hospitalized patients.

Therefore, the inclusion of correct information dissemination within the hospital environment, as well as their amplification strategies, is extremely important, since the lack of knowledge about $A E$, the prevention of these errors, the lack of communication and the lack of improvements in basic patient safety techniques can put the child's hospitalization at risk.

\section{Limitations of the study}

It was possible to notice in some studies included in this review the lack of detailed information regarding the characteristics of the engagement strategies used and their evaluation process by the participants. Furthermore, some databases do not use controlled descriptors, which may favor missing studies.

\section{Contributions to the area of nursing}

The results found favor discussions on the understanding of the companions' participation in the promotion of PS, in addition to contributing to the planning and implementation of strategies aimed at encouraging the involvement of these companions and, consequently, offering safer care to children and newborns.

\section{FINAL CONSIDERATIONS}

The study allowed unveiling how companions and health professionals in pediatrics and neonatology perceive their involvement in PS, the facilitating and hindering aspects and the strategies that aim for this purpose.

\section{FUNDING}

The authors did not receive any financial support for developing this research, analyzing data or submitting this manuscript. 


\section{REFERENCES}

1. World Health Organization. Patient safety: about us [Internet]. Geneva: WHO; c2009-2016[cited 2016 Dec 02]; [about 2 screens]. Available from: http:// www.who.int/patientsafety/about/en/

2. Agência Nacional de Vigilância Sanitária (BR). Assistência segura: uma reflexão teórica aplicada à prática agência nacional de vigilância sanitária. Brasília, DF: Anvisa; 2017.

3. Ministério da Saúde (BR). Documento de referência para o programa nacional de segurança do paciente. Brasília, DF; MS; 2014.

4. Longtin Y, Sax H, Leape LL, Sheridan SE, Donaldson L, Pittet D. Patient participation: current knowledge and applicability to patient safety. Mayo Clin Proc. 2010;85(1):53-62. https://doi.org/10.4065/mcp.2009.0248

5. Souliotis K, Agapidaki E, Peppou LE, Tzavara C, Varvaras D, Buonomo OC, et al. Assessing patient organization participation in health policy: a comparative study in France and Italy. Int J Health Policy Manag. 2018;7(1):48-58. https://doi.org/10.15171/ijhpm.2017.44

6. Heath S. Distinguishing and defining top patient engagement keywords. Patient Engagement Hit [Internet]. 2018 Aug 28; [about 3 screens]. Available from: https://patientengagementhit.com/news/distinguishing-and-defining-top-patient-engagement-keywords

7. Silva CB, Silva DG, Carvalho LL, Goulart CL, Silva, ALG, Angri D. Ocorrência de eventos adversos em unidade de terapia intensiva neopediátrica. Rev Epidemiol Control Infecc. 2017;7(4):2238-3360. http://doi.org/10.17058/reci.v7i4.7564

8. Harada MJCS, Chanes DC, Kusahara DM, Pedreira MLG. Safety in medication administration in pediatrics. Acta Paul Enferm. 2012;25(4):63942. https://doi.org/10.1590/S0103-21002012000400025

9. Stockwell DC, Bisarya H, Classen DC, Kirkendall ES, Landrigan CP, Lemon V, et al. A trigger tool to detect harm in pediatric inpatient settings. Pediatrics. 2015;135(6):1036-42. https://doi.org/10.1542/peds.2014-2152

10. Trier $\mathrm{H}$, Valderas JM, Wensing M, Martin HM, Egebart J. Involving patients in patient safety programmes: a scoping review and consensus procedure by the LINNEAUS collaboration on patient safety in primary care. Eur J Gen Pract. 2015;21(suppl 1):56-61. https://doi.org/10.3109 $/ 13814788.2015 .1043729$

11. Cavalcante AK, Cavalcante FA, Pires DC, Batista EM, Nogueira LT. Nursing perception of safety culture: integrative review. J Nurs UFPE. 2016;10(10):3890-7. https://doi.org/10.5205/1981-8963-v10i10a11457p3890-3897-2016

12. Skagerström J, Ericsson C, Nilsen P, Ekstedt M, Schildmeijer K. Patient involvement for improved patient safety: a qualitative study of nurses' perceptions and experiences. Nurs Open. 2017;4(4):230-9. https://doi.org/10.1002/nop2.89

13. Azevedo AP, Cristino JS, Viana MF, Medeiros FP, Azevedo LS. Health education for companions of hospitalized patients. J Nurs UFPE. 2018;12(4);1168-73. https://doi.org/10.5205/1981-8963-v12i4a230649p1168-1173-2018

14. Ricciardi R, Shofer M. Nurses and patients: natural partners to advance patient safety. J Nurs Care Qual. 2019;34(1):1-3. https://doi. org/10.1097/NCQ.0000000000000377

15. Melo EMOP, Ferreira PL, Lima RAG, Mello DF. The involvement of parents in the healthcare provided to hospitalized children. Rev Latino-Am Enfermagem. 2014;22(3):432-9. https://doi.org/10.1590/0104-1169.3308.2434

16. Neves L, Gondim AA, Soares SC, Coelho DP, Pinheiro JA. The impact of the hospitalization process on the caregiver of a chronic critical patient hospitalized in a semi-intensive care unit. Esc Anna Nery. 2018;22(2):e20170304. https://doi.org/10.1590/2177-9465-EAN-2017-0304

17. Brito MVN, Ribeiro DE, Lima RS, Gomes RG, Fava SMCL, Vilela SD, et al. Role of the companion in hospitalization: nursing professional's perspective. J Nurs UFPE. 2020;14:e243005. https://doi.org/10.5205/1981-8963.2020.243005

18. Ministério da Saúde (BR). Resolução $n^{\circ} 466$, de 12 de dezembro de 2012. Diretrizes e normas regulamentadoras de pesquisas envolvendo seres humanos [Internet]. Brasília, DF: MS; 2012.

19. Peters MDJ, Godfrey C, Mclnerney P, Munn Z, Tricco AC, Khalil, H. Scoping reviews: 2020. In: Aromataris E, Munn Z, editors. JBI manual for evidence synthesis. Adelaide: JBI; 2020. Chapter 11. https://doi.org/10.46658/JBIMES-20-12

20. Tricco AC, Lillie E, Zarin W, O'Brien KK, Colquhoun H, Levac D, et al. PRISMA extension for scoping reviews (PRISMA-ScR): checklist and explanation. Ann Intern Med. 2018;169(7):467-73. https://doi.org/10.7326/M18-0850

21. Melnyk BM, Fineout-Overholt E. Evidencebased practice in nursing and healthcare: a guide to best practice. Philadelphia: Lippincot Williams \& Wilkins; 2005. Making the case for evidence-based practice; p. 3-24.

22. Biasibetti C, Hoffmann LM, Rodrigues FA, Wegner W, Rocha PK. Communication for patient safety in pediatric hospitalizations. Rev Gaucha Enferm. 2019;40(esp):e20180337. https://doi.org/10.1590/1983-1447.2019.20180337

23. Corbally MT, Tierney E. Parental involvement in the preoperative surgical safety checklist is welcomed by both parents and staff. Int J Pediatr. 2014;2014:791490. https://doi.org/10.1155/2014/791490

24. Gonçalves KMM, Costa MTTCA, Silva DCB, Baggio ME, Corrêa AR, Manzo BF. Ludic strategy for promoting engagement of parents and caregivers in the safety of pediatric patients. Rev Gaucha Enferm. 2020;41:e20190473. https://doi.org/10.1590/1983-1447.2020.20190473

25. Hoffman MR, Wegner W, Biasibetti C, Peres MA, Gerhardt LM, Breigeiron MK. Patient safety incidents identified by the caregivers of hospitalized children. Rev Bras Enferm. 2019;72(3):707-14. http://doi.org/10.1590/0034-7167-2018-0484 
26. Hoffman LM, Rodrigues FA, Biasibetti C, Peres MA, Vaccari A, Wegner W. Patient safety incidents reported by relatives of hospitalized children Rev Gaucha Enferm. 2020;41(esp):e20190172. https://doi.org/10.1590/1983-1447.2020.20190172

27. Khan A, Coffey M, Litterer KP, Baird JD, Furtak SL, Garcia BM. et al. Families as partners in hospital error and adverse event surveillance. JAMA Pediatr. 2017;171(4):372-81. https://doi.org/10.1001/jamapediatrics.2016.4812

28. Lyndon A, Jacobson CH, Fagan KM, Wisner K, Franck LS. Parents' perspectives on safety in neonatal intensive care: a mixed-methods study. BMJ Qual Saf. 2014;23(11):902-9. https://doi.org/10.1136/bmjqs-2014-003009

29. Massa ER, Hooker AC, García Martínez DG. Condiciones de seguridad percibidas por cuidadores familiares en atención pediátrica. Rev Cienc Cuidad. 2019;16(3):80-92. https://doi.org/10.22463/17949831.1574

30. Peres MA, Wegner W, Cantarelli-Kantorski KJ, Gerhardt LM, Magalhães AMM. Perception of family members and caregivers regarding patient safety in pediatric inpatient units. Rev Gaucha Enferm. 2018;39:e2017-0195. http://doi.org/10.1590/1983-1447.2018.2017-0195

31. Rodrigues FA, Wegner W, Kantorski KJC, Pedro ENR. Patient safety in a neonatal unit: concerns and strategies experienced by parent. Cogitare Enferm. 2018;23(2):e52166. http:// doi.org/10.5380/ce.v23i1.52166

32. Rosenberg RE, Williams E, Ramchandani N, Rosenfeld P, Silber B, Schlucter J, et al. Provider perspective on partnering with parents of hospitalized children to improve safety. Hosp Pediatr. 2018;8(6):330-7. https://doi.org/10.1542/hpeds.2017-0159

33. Silva TD, Wegner W, Pedro EN. Segurança da criança hospitalizada na UTI: compreendendo os eventos adversos sob a ótica do acompanhante. Rev Eletr Enferm. 2012;14(2):337-44. http://doi.org/10.5216/ree.v14i2.12977

34. Souza FCP, Montenegro LC, Goveia VR, Corrêa AR, Rocha PK, Manzo BF. Family participation in patient safety in neonatal units from the nursing perspective. Texto Contexto Enferm. 2017;26(3):e1180016. https://doi.org/10.1590/0104-07072017001180016

35. Oyesanya TO, Bowerd B. "I'm trying to be the safety net": family protection of patients with moderate-to-severe TBI during the hospital stay. Qual Health Res. 2017;27(12):1804-15. https://doi.org/10.1177/1049732317697098

36. Leonard MS. Patient Safety and Quality Improvement: reducing risk of harm. Pediatr Rev. 2015;36(10):448-56. https://doi.org/10.1542/pir.36-10-448

37. Santos PRA, Rocha FLR, Sampaio CSJC. Actions for safety in the prescription, use and administration of medications in emergency care units. Rev Gaucha Enferm. 2019;40(esp):e20180347. https://doi.org/10.1590/1983-1447.2019.20180347

38. Franco LF, Bonelli MA, Wernet M, Barbieri MC, Dupas G. Patient safety: perception of family members of hospitalized children. Rev Bras Enferm. 2020;73(5):e20190525. https://doi.org/10.1590/0034-7167-2019-0525

39. Souza FT, Garcia MC, Rangel PPS, Rocha PK. Percepção da enfermagem sobre os fatores de risco que envolvem a segurança do paciente pediátrico. Rev Enfem. 2014;4(1):152-62. https://doi.org/10.5902/217976928781

40. Hoffmeister LV, Moura GMSS. Use of identification wristbands among patients receiving inpatient treatment in a teaching hospital. Rev Latino-Am Enfermagem. 2015;23(1):36-43. https://doi.org/10.1590/0104-1169.0144.2522

41. Parcianello AT, Felin RB. E agora doutor, onde vou brincar?: considerações sobre a hospitalização infantil. Barbaroi. 2008;28:147-66. http:// doi.org/10.17058/barbaroi.v0i0.356

42. Fernandes CS, Martins MM, Gomes BP, Gomes JA, Gonçalves LHT. Family nursing game: developing a board game. Esc Anna Nery. 2016;20(1):33-7. https://doi.org/10.5935/1414-8145.20160005 